\title{
MicroRNA Expression Profile
}

National Cancer Institute

\section{Source}

National Cancer Institute. MicroRNA Expression Profile. NCI Thesaurus. Code C129767.

An analysis of all of the microRNA molecules expressed in a biological sample. 